\title{
STUDIES ON GANGRENE FOLLOWING COLD INJURY. VIII. THE USE OF CASTS AND PRESSURE DRESSINGS IN THE TREATMENT OF SEVERE FROSTBITE ${ }^{1}$
}

\author{
By J. M. CRISMON AND F. A. FUHRMAN \\ (From the Department of Physiology, School of Medicine, Stanford University, California)
}

(Received for publication December 16, 1946)

It has been reported in a previous communication (1) that increased leakage of fluid from capillaries is an invariable consequence of cold injury in rabbits' ears and feet. Although stasis in the true capillaries was observed to occur in ears about 10 minutes after injury, it could be delayed by several procedures (2). The delayed appearance of stasis in the treated ears, as well as the invariable late occurrence of stasis at the junction between the normal and frostbitten regions of an ear, suggest that distortion of the tissues, resulting from the massive edema, may close true capillaries and produce stasis. The effect of capillary closure in limiting the exchanges between the blood stream and the cells is an important one.

The similarity between the vascular lesion in frostbite and in burns is obvious and has been pointed out previously by others (3). Glenn (4) has recently reviewed the development of the treatment of burns by means of external pressure and by means of non-elastic, non-distensible dressings. Whether the good results of these forms of treatment depend upon "the control of capillary leakage" as suggested by Glenn or whether the benefit may derive from prevention of the mechanical distortion produced by swelling has not been determined. However, measures which aim at the control of either of these consequences of heat injury find equal justification for their use in the treatment of frostbite.

Two different types of dressings are available for the mechanical control of fluid loss following injury :

(a) Closed plaster casts were used by Glenn, Gilbert, and Drinker (5) for the treatment of experimental burns. The rationale of this procedure has been described by Glenn (4) : "As plasma es-

1 The work described in this paper was done under a contract, recommended by the Committee on Medical Research, between the Office of Scientific Research and Development and Stanford University. capes from the dilated hyperpermeable capillaries, the extravascular tissue fluid pressure quickly builds up against the rigid encasement to exactly equal the pressure attempting to push fluid out of the capillaries." Such dressings should be skintight, non-elastic and non-distensible. In order to be maximally effective they .should be applied before swelling of the injured part has taken place, and they must be applied in such a way that the distal part of the limb is encased in the dressing.

(b) External pressure to control fluid loss, as used by Allen and Koch (6) and others, is applied in the form of a pressure dressing of elastic material. A layer of padding separates the tissue from the elastic bandage and serves to equalize the pressures within the dressing. This form of dressing offers no obvious advantages over rigid casts for immediate treatment of frostbite in the period before swelling has begun.

\section{METHODS}

Standard cold injury. Injury was produced by immersing the hind feet of rabbits in a mixture of water, ethylene glycol, and alcohol cooled by the addition of solid carbon dioxide. The times of exposure and the temperatures used included those from 15 to 60 minutes at $-15^{\circ}$ $\mathrm{C}$. and 2 and 3 minutes at $-55^{\circ} \mathrm{C}$. Details of standardization of cold injury produced by this means are given in the first paper of this series (7).

Closed plaster and plastic dressings. Closed plaster casts were prepared by impregnation of 1-inch gauze strips with dental "flasking" plaster. These were wetted and applied over a thin layer of gauze.

In order to prepare a light weight, non-distensible dressing which would serve a purpose similar to that of closed plaster casts, dressings were made from solutions of plastic materials applied to gauze. Most of the closed plastic dressings were made of a solution of polyvinyl butyral in isopropyl alcohol and castor oil ("Sealskin"). ${ }^{2}$ Some were formed with acetone solutions of 40 per cent isobutyl methacrylate or methacrylate interpolymer. ${ }^{3}$ Those made of "Sealskin" proved to be most satisfactory;

2 "Sealskin-viscous," Clay-Adams \& Co., N. Y.

${ }^{3}$ Kindly supplied by E. I. duPont de Nemours, Ammonia Dept., Wilmington, Del. 
examples are shown in Figure 1. The dried cast was very light in weight, non-distensible, and non-elastic, but to some extent permeable to air. Those made from the methacrylates were more rigid, less permeable to air, and tended to shrink slightly after application.

In most cases closed plaster and plastic dressings were applied to the feet of rabbits after thawing had taken place, but before swelling was noticeable. Upon measurement of foot volume immediately before application of the cast it was usually found to have increased about $1 \mathrm{ml}$. In a few animals the casts were applied before thawing was complete. The results did not differ from those first described. All feet had been freed of hair by close clipping before injury. The alcohol-ethylene glycol-water solution (7) in which the frostbite was produced was removed from the foot by gentle wiping. Tincture of merthiolate was usually used as a surface antiseptic, although this was sometimes omitted. Next a thin layer of $\mathrm{K}-\mathrm{Y}$ jelly or of petrolatum was applied. Each toe was separated from the next by means of gauze, cotton, paper wadding, or lamb's wool. A thin layer of the padding was also uniformly distributed around the foot. Over this was applied 1 layer of seamless tubular gauze, then 2 to 3 layers of 1 -inch gauze followed by 2 layers of seamless tubular gauze. The plastic solution was applied with a wooden tongue depressor in 2 coats; 1 over the gauze strips and 1 over the final layer of tubular gauze. The feet were then dried for 20 to 30 minutes in the air stream from a fan. The plastic dressing covered the entire foot and extended as far proximally as possible without impairing ankle flexion.

Pressure dressings. Pressure dressings were always applied after swelling was well started or after it had reached a maximum. They were constructed of approximately 2.5 yards (stretched length) of 1-inch wide elastic bandage. Both "Ace" and "Adaptic" bandages were used; standard 2-inch widths were cut lengthwise before use. Padding material was applied in $a^{\prime}$ thicker layer than was used under closed plastic dressings. Of the 30 pressure dressings used, 24 were padded with lamb's wool, 4 with cotton and 1 each with paper wadding or gauze. Care was taken to begin tight application of the bandage distally and work as far toward the ankle as full flexion of this joint would permit.

RESULTS OBTAINED BY THE USE OF CLOSED PLASTER

\section{AND PLASTIC DRESSINGS AND THEIR COMBINA- TION WITH WARMING AND COOLING}

For convenience of comparison of results following various types of treatment with appropriate untreated controls, the following classification of tissue loss in the order of increasing severity was used (Table I) :

I. Partial loss of the toes.

II. Complete loss of the toes.

III. Loss of all tissue distal to a line $1.5 \mathrm{~cm}$. from the level of frostbite.
IV. Loss of all tissue distal to a line $1.0 \mathrm{~cm}$. from the level of frostbite.

V. Loss of all tissue distal to a line $0.5 \mathrm{~cm}$. from the level of frostbite.

VI. Loss of all tissue except a narrow extension of the plantar pad.

VII. Loss of all tissue to the level of frostbite.

Table I indicates in the first column the type of treatment, the time of exposure, and temperature of the freezing mixture used to produce injury.

Closed plaster and plastic dressings. Closed plaster casts were applied to rabbits' feet following 3 -minute exposure at $-52^{\circ} \mathrm{C}$. to $-55^{\circ} \mathrm{C}$.; closed plastic dressings were applied following 3minute exposure at $-53^{\circ} \mathrm{C}$. to $-56^{\circ} \mathrm{C}$., 2 -minute exposure at $-54^{\circ} \mathrm{C}$., and 60 -minute exposure at $-15^{\circ} \mathrm{C}$. The results as shown in Table I indicate the number of times each degree of tissue loss was encountered in untreated controls and treated animals. The efficacy of this form of treatment may be seen from comparison with data on similar untreated injuries. It is apparent that the most striking results were obtained when the treatment was applied to frostbite of 3-minute duration at $-55^{\circ} \mathrm{C}$. (a severe injury, which usually resulted in complete loss of the foot to the level of frostbite). Of 7 animals, frostbitten for 3 minutes at $-55^{\circ} \mathrm{C}$. and treated by means of plaster or plastic casts padded only with gauze, 6 animals lost only toes or parts of toes. A typical result of this treatment is shown in Figure 1. It is apparent that too early removal of casts is disastrous; those animals frostbitten 60 minutes at $-15^{\circ} \mathrm{C}$. with casts removed after 2 and 3 days (see examples marked * in Table I) lost the entire injured region.

Rapid warming followed by closed plastic dressings. The feet of 6 animals were exposed at $-53^{\circ} \mathrm{C}$. to $-55^{\circ} \mathrm{C}$. for 3 minutes, then rapidly warmed in water for 5 minutes at $+42^{\circ} \mathrm{C}$. and encased immediately in closed plastic (Sealskin) dressings padded with a minimum amount of lamb's wool. While without treatment none of the 17 animals subjected to this degree of injury retained more than $1.5 \mathrm{~cm}$. of the injured part of the foot, all 6 treated by rapid warming plus plastic dressings lost only the toes or parts of the toes (Table I).

Closed plastic dressings followed by cooling. Six rabbits are included in this series (Tables I and 

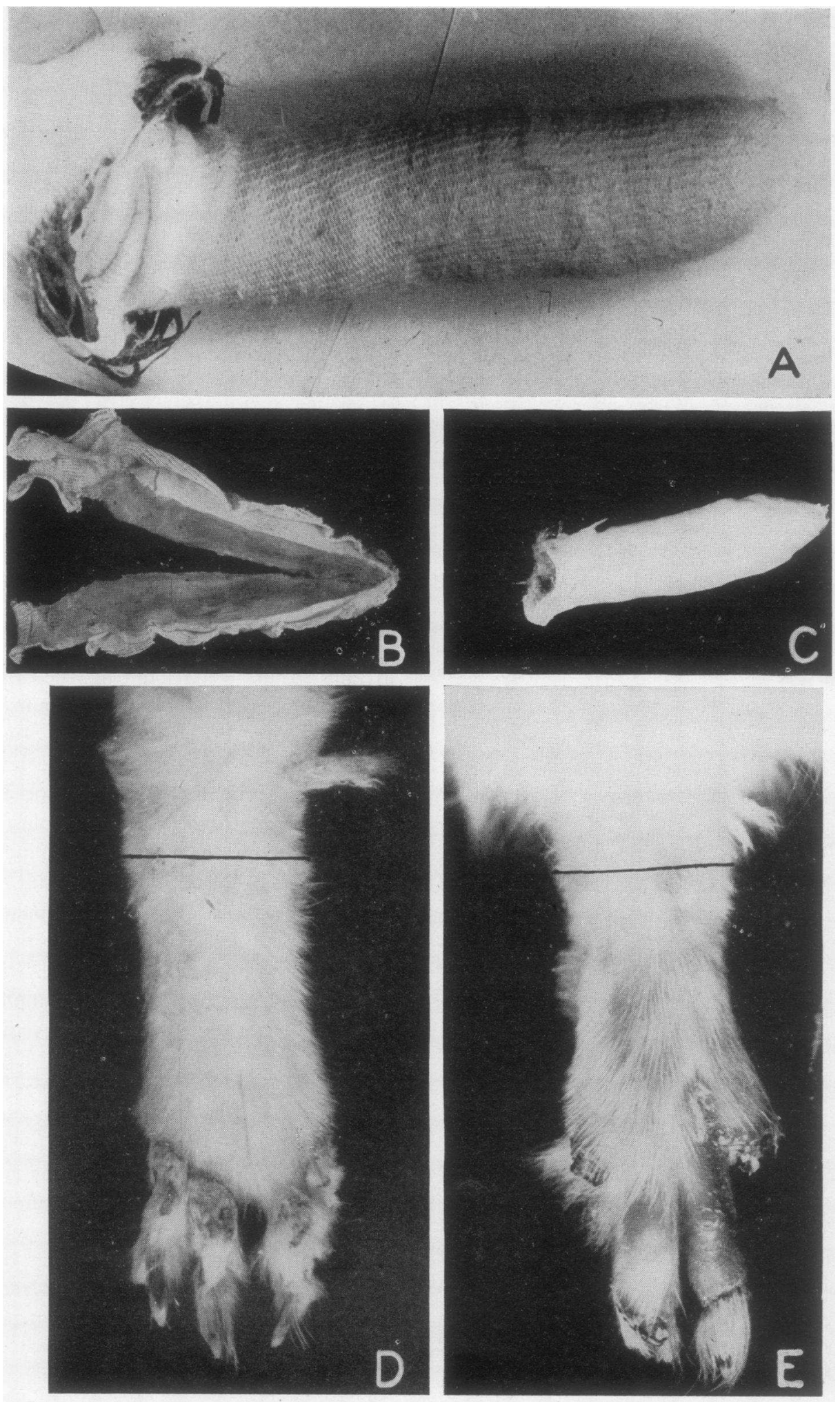

FIG. 1. 
TABLE I

The loss of tissue sustained in rabbits' feet following various types of treatment of experimental frostbite

\begin{tabular}{|c|c|c|c|c|c|c|c|c|}
\hline \multirow[b]{2}{*}{ Treatment } & \multirow[b]{2}{*}{$\begin{array}{c}\text { Degree of } \\
\text { tissue loss } \\
\begin{array}{c}\text { Total number } \\
\text { animals }\end{array}\end{array}$} & \multicolumn{7}{|c|}{ Number of animals sustaining each degree of tissue loss } \\
\hline & & $\mathbf{I}$ & $\begin{array}{l}\text { II } \\
1 \\
\end{array}$ & III & IV & $\mathbf{v}$ & VI & VII \\
\hline $\begin{array}{l}\text { Untreated controls } \\
3 \text { min. at }-55^{\circ} \mathrm{C} . \\
2 \text { min. at }-55^{\circ} \mathrm{C} \text {. } \\
60 \text { min. at }-15^{\circ} \mathrm{C} \text {. }\end{array}$ & $\begin{array}{r}17 \\
5 \\
4\end{array}$ & $\begin{array}{l}\mathbf{0} \\
\mathbf{0} \\
\mathbf{0}\end{array}$ & $\begin{array}{l}\mathbf{0} \\
\mathbf{4} \\
1\end{array}$ & $\begin{array}{l}1 \\
0 \\
0\end{array}$ & $\begin{array}{l}2 \\
0 \\
1\end{array}$ & $\begin{array}{l}1 \\
0 \\
0\end{array}$ & $\begin{array}{l}6 \\
1 \\
1\end{array}$ & $\begin{array}{l}7 \\
0 \\
1\end{array}$ \\
\hline $\begin{array}{l}\text { Closed plaster casts } \\
\quad 3 \text { min. at }-55^{\circ} \mathrm{C} .\end{array}$ & 4 & 1 & 3 & $\mathbf{0}$ & $\mathbf{0}$ & $\mathbf{0}$ & 0 & 0 \\
\hline $\begin{array}{l}\text { Closed plastic dressings } \\
3 \text { min. at }-55^{\circ} \mathrm{C} . \\
2 \text { min. at }-55^{\circ} \mathrm{C} . \\
60 \text { min. at }-15^{\circ} \mathrm{C} .\end{array}$ & $\begin{array}{l}9 \\
5 \\
4\end{array}$ & $\begin{array}{l}3 \\
2 \\
1\end{array}$ & $\begin{array}{l}0 \\
3 \\
1\end{array}$ & $\begin{array}{l}\mathbf{0} \\
0 \\
0\end{array}$ & $\begin{array}{l}\mathbf{0} \\
\mathbf{0} \\
\mathbf{0}\end{array}$ & $\begin{array}{l}0 \\
0 \\
0\end{array}$ & $\begin{array}{l}4 \\
0 \\
0\end{array}$ & $\begin{array}{l}2 \\
0 \\
2^{*}\end{array}$ \\
\hline $\begin{array}{l}\text { Rapid warming plus plastic dressings } \\
3 \text { min. at }-55^{\circ} \mathrm{C} \text {. }\end{array}$ & 6 & 1 & 4 & 0 & $\mathbf{0}$ & 0 & 1 & 0 \\
\hline $\begin{array}{l}\text { Plastic dressings plus cooling } \\
3 \text { min. at }-55^{\circ} \mathrm{C} \text {. }\end{array}$ & 6 & 0 & 3 & 0 & 0 & 0 & 1 & 2 \\
\hline $\begin{array}{l}\text { Rapid warming, plastic dressing, and } \\
\text { cooling } \\
3 \text { min. at }-55^{\circ} \mathrm{C} .\end{array}$ & 5 & 1 & 1 & 0 & 2 & $\mathbf{0}$ & 0 & 1 \\
\hline $\begin{array}{l}\text { Pressure dressing } \\
3 \mathrm{~min} . \text { at }-55^{\circ} \mathrm{C} . \\
2 \mathrm{~min} . \text { at }-55^{\circ} \mathrm{C} . \\
60 \mathrm{~min} \text {. at }-15^{\circ} \mathrm{C} .\end{array}$ & $\begin{array}{l}7 \\
5 \\
3\end{array}$ & $\begin{array}{l}0 \\
4 \\
3\end{array}$ & $\begin{array}{l}4 \\
1 \\
0\end{array}$ & $\begin{array}{l}0 \\
0 \\
0\end{array}$ & $\begin{array}{l}0 \\
0 \\
0\end{array}$ & $\begin{array}{l}\mathbf{0} \\
\mathbf{0} \\
\mathbf{0}\end{array}$ & $\begin{array}{l}\mathbf{0} \\
\mathbf{0} \\
\mathbf{0}\end{array}$ & $\begin{array}{l}3 \\
0 \\
0\end{array}$ \\
\hline $\begin{array}{l}\text { Rapid warming plus pressure dressing } \\
3 \mathrm{~min} . \text { at }-55^{\circ} \mathrm{C} . \\
60 \mathrm{~min} \text {. at }-15^{\circ} \mathrm{C} .\end{array}$ & $\begin{array}{l}5 \\
3\end{array}$ & $\begin{array}{l}2 \\
3\end{array}$ & $\begin{array}{l}3 \\
0\end{array}$ & $\begin{array}{l}\mathbf{0} \\
\mathbf{0}\end{array}$ & $\begin{array}{l}\mathbf{0} \\
\mathbf{0}\end{array}$ & $\begin{array}{l}\mathbf{0} \\
\mathbf{0}\end{array}$ & $\begin{array}{l}\mathbf{0} \\
\mathbf{0}\end{array}$ & $\begin{array}{l}\mathbf{0} \\
\mathbf{0}\end{array}$ \\
\hline $\begin{array}{l}\text { Multiple incision plus pressure } \\
\text { dressing } \\
\quad 3 \text { min. at }-55^{\circ} \mathrm{C} \text {. }\end{array}$ & 7 & 0 & 2 & 1 & 0 & $\mathbf{0}$ & 1 & 3 \\
\hline $\begin{array}{l}\text { Pulsating pressure } \\
3 \mathrm{~min} . \text { at }-55^{\circ} \mathrm{C} . \\
2 \mathrm{~min} \text {. at }-55^{\circ} \mathrm{C} .\end{array}$ & $\begin{array}{r}13 \\
2\end{array}$ & $\begin{array}{l}0 \\
1\end{array}$ & $\begin{array}{l}1 \\
0\end{array}$ & $\begin{array}{l}0 \\
0\end{array}$ & $\begin{array}{l}2 \\
0\end{array}$ & $\begin{array}{l}1 \\
0\end{array}$ & $\begin{array}{l}0 \\
1\end{array}$ & $\begin{array}{l}9 \\
0\end{array}$ \\
\hline
\end{tabular}

* The dressings were removed from the feet of these animals on the second and third day after injury.

II). Following 3-minute exposure of the foot at the foot was then cooled for 6 to 8 hours. Thermo$-55^{\circ}$ C., a closed plastic (Sealskin) dressing couples were placed inside the dressings of rabbits was applied, permitted to dry 15 to 20 minutes, and 84,88 , and 98 in order that the temperature of the

Fig. 1. A. Rabbit Foot Enclosed in "Sealskin" Plastic Cast

Leads from thermocouples enclosed in cast are wound around the ankle.

B. "Sealskin" Plastic Cast Removed from Rabbit Foot and Opened to Show Padding

C. Methacrylate Plastic Cast after Removal from Rabbit Foot

D. Rabbit Foot Photographed 15 Days after Frostbite for 3 Min. at - 54 C.

Plastic cast applied after thawing and left in place for 7 days.

E. Rabbit Foot Photographed 18 Days after Frostbite for 3 Min. at $-54^{\circ} \mathrm{C}$.

Pressure dressing applied 31/2 hours after injury and left in place for 4 days. The level of immersion in the freezing mixture is indicated in $\mathrm{D}$ and $\mathrm{E}$ by the transverse inked line. 
TABLE II

Treatment of frostbite by closed plastic dressings plus cooling

Feet exposed at $-54^{\circ} \mathrm{C}$. to $-56^{\circ} \mathrm{C}$. for 3 minutes. Closed plastic dressing applied after thawing. Cooling began immediately after dressing dried (about 15 minutes).

\begin{tabular}{|c|c|c|c|}
\hline $\begin{array}{c}\text { Ani- } \\
\text { mal } \\
\text { num- } \\
\text { ber }\end{array}$ & Cooling & $\begin{array}{l}\text { Days } \\
\text { dress- } \\
\text { ing } \\
\text { left } \\
\text { in } \\
\text { place }\end{array}$ & Result \\
\hline 84* & $\begin{array}{l}\text { Cooled to }+5^{\circ} \text { to }+15^{\circ} \mathrm{C} \text {. } \\
\text { for } 6 \text { hours }\end{array}$ & 5 & Lost to level of frostbite \\
\hline $\begin{array}{l}87 \\
88 *\end{array}$ & $\begin{array}{l}\text { Packed in ice } 8 \text { hours } \\
\text { Cooled to }+1^{\circ} \text { to }+5^{\circ} \mathrm{C} \text {. } \\
\text { for } 7 \text { hours }\end{array}$ & $\begin{array}{l}5 \\
6\end{array}$ & $\begin{array}{l}\text { Lost to level of frostbite } \\
\text { Lost toes }\end{array}$ \\
\hline $\begin{array}{l}98 * \\
103\end{array}$ & $\begin{array}{l}\text { Cooled to }+10^{\circ} \mathrm{C} .7 \text { hours } \\
\text { Cooled in ice } 7 \text { hours }\end{array}$ & $\begin{array}{l}5 \\
6\end{array}$ & $\begin{array}{l}\text { Lost toes } \\
\text { Lost to level of frostbite } \\
\text { except } 3 \mathrm{~cm} \text {. tongue of }\end{array}$ \\
\hline 104 & Cooled in ice 7 hours & 6 & Lost toes \\
\hline
\end{tabular}

* Thermocouples placed inside dressing.

foot could be maintained at $5^{\circ}$ to $10^{\circ} \mathrm{C}$. during the cooling period. Three of these animals lost only the toes, while 3 lost an amount of tissue similar to that in untreated animals.

Rapid warming followed by closed plastic dressings and cooling. In 5 animals the treatments used above were combined. Immediately after injury (by exposure of the foot for 3 minutes at $-55^{\circ}$ C.), the foot was warmed 5 minutes in water at $+42^{\circ} \mathrm{C}$., encased in a plastic (Sealskin) dressing, and then cooled with ice during the next 5 to 6.5 hours (Tables I and III). This procedure did not seem to produce results superior to those obtained by closed dressings alone or by rapid warming followed by closed plastic dressings.

TABLE III

Treatment of frostbite by immediate rapid warming plus closed plastic dressings plus cooling

Feet exposed at $-53^{\circ} \mathrm{C}$. to $-55^{\circ} \mathrm{C}$. for 3 minutes, warmed in water at $+42^{\circ} \mathrm{C}$. for 5 minutes. Closed plastic dressing applied immediately af ter warming; cooling began immediately after dressing dried (about 15 minutes).

\begin{tabular}{|c|c|c|}
\hline Cooling & $\begin{array}{l}\text { Days } \\
\text { dressing } \\
\text { left in } \\
\text { place }\end{array}$ & Result \\
\hline $\begin{array}{l}\text { Cooled at }+5 \text { to }+12^{\circ} \mathrm{C} . \\
\text { for } 5 \text { hours } 6.5 \text { hours } \\
\text { Cooled in ice } 6.5 \text { houl }\end{array}$ & $\begin{array}{l}7 \\
7\end{array}$ & $\begin{array}{l}\text { Lost distal and middle pha- } \\
\text { langes of all toes } \\
\text { Lost to } 1 \mathrm{~cm} \text {. distal to level }\end{array}$ \\
\hline $\begin{array}{l}\text { Cooled in ice } 6 \text { hours } \\
\text { Cooled in ice } 6 \text { hours }\end{array}$ & $\begin{array}{l}7 \\
6\end{array}$ & $\begin{array}{l}\text { Lost toes } \\
\text { Lost to } 1 \mathrm{~cm} \text {. distal to level }\end{array}$ \\
\hline Cooled in ice 6 hours & 6 & Lost to level of frostbite \\
\hline
\end{tabular}

TEMPERATURE MEASUREMENTS OF FOOT ENCASED IN PLASTIC DRESSINGS

Method. In 11 animals thermocouples were placed on the toes or on the dorsum of the foot, or both, before application of the plastic dressings. The thermocouple leads were brought out through the proximal end of the dressing and were wrapped around the animal's leg, as shown in Figure 1, so as not to interfere with its movement in the cage when temperatures were not being measured. Temperature measurements were made with a Leeds and Northrup Potentiometer Indicator using iron-constantan thermocouples attached to copper discs $7 \mathrm{~mm}$. in diameter.

In 6 of the animals the thermocouples were primarily for the purpose of measuring the temperature inside the dressings during cooling of the feet following injury. Measurements of the temperatures were, however, continued for the period during which the dressing was left in place.

In the remaining animals, temperature measurements were made during the first several hours after application of the dressing and at intervals during the ensuing 5 to 7 days. It was found that the temperature of the foot inside the dressing gave an accurate indication of the blood supply to the injured part. In those feet or parts of feet which were subsequently lost, the temperature (measured by the thermocouples within the dressing) either failed to rise above about $26^{\circ} \mathrm{C}$. to $29^{\circ} \mathrm{C}$. or fell to this level after 24 to 48 hours. Figure 2 shows temperature measurements of the toes and dorsal surface of the feet of 2 animals during the period that the dressings were in place. In both instances the feet were exposed for 3 minutes at $-55^{\circ}$ C. Plastic (Sealskin) dressings were applied immediately after thawing occurred. In No. 32, padding was used between the toes and around the foot in such a manner that uneven pressure was avoided. The temperature of both the toes and dorsum increased rapidly and remained high throughout the period of measurement. Tissue loss was confined to 1 toe. In No. 30, no padding of any kind was used between the toes and it was afterward found that excessive pressure occurred around the base of the metatarsals. In this animal the temperature within the dressing increased more slowly, never exceeded $30^{\circ} \mathrm{C}$., and fell again after 24 hours. Loss of the entire injured area with the exception of a narrow segment on the plantar surface occurred.

The incorporation of thermocouples for frequent measurement of skin temperature within closed dressings employed in human surgery might offer a convenient and accurate means of determining the state of blood flow to the part when it is not possible to determine this by direct observation. 


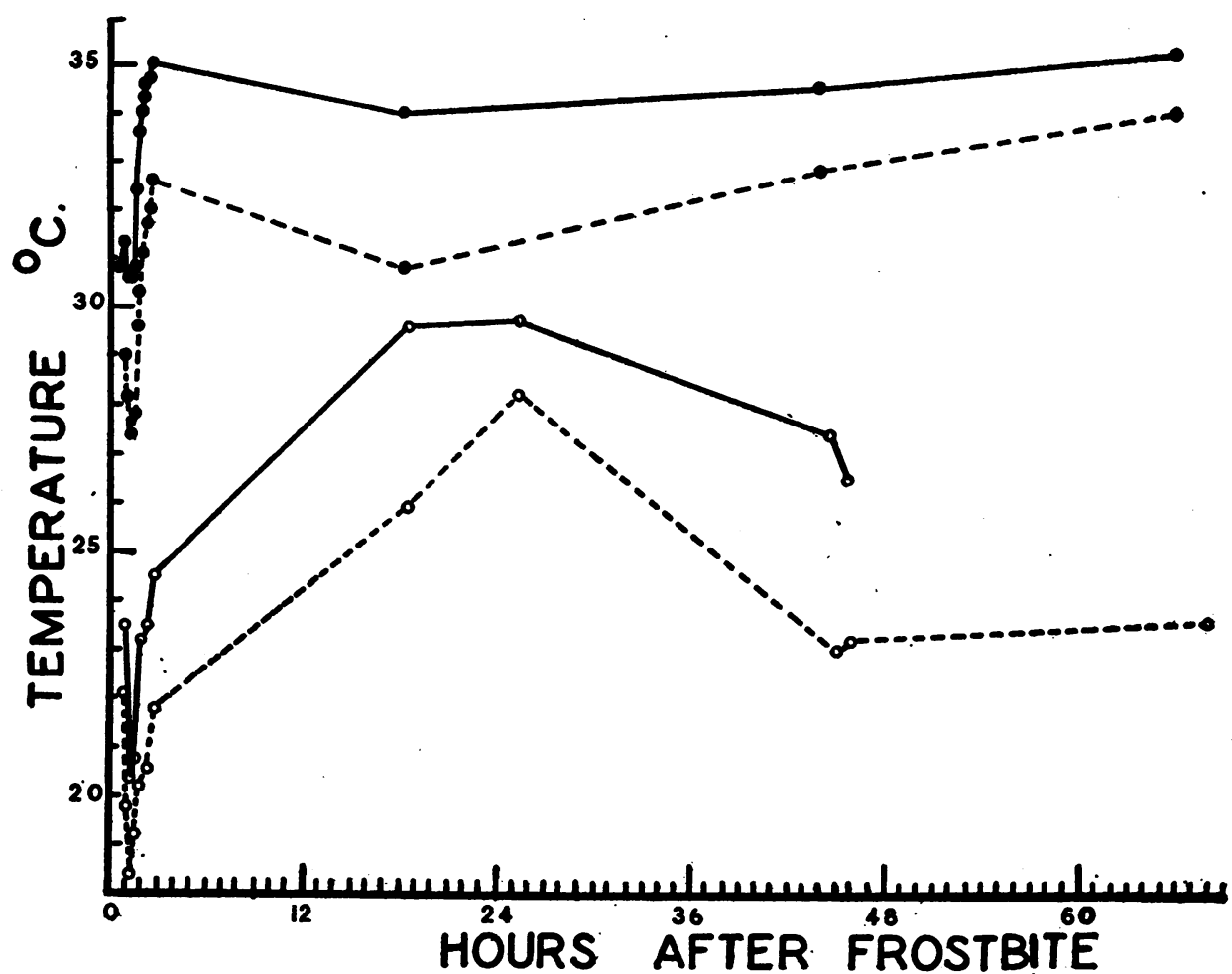

Fig. 2. Temperatures of Rabbits' Feet in Padded and Unpadded Plastic Casts

Feet exposed for 3 minutes at $-55^{\circ} \mathrm{C}$. Thermocouples placed on dorsum of foot and between toes before application of cast. Representative data from 2 animals.

Solid circles and solid line-temp. of dorsum in padded cast. Solid circles and broken linetemp. of toes in padded cast. Open circles and solid line-temp. of dorsum in unpadded cast. Open circles and broken line-temp. of toes in unpadded cast.

RESULTS OBTAINED BY THE USE OF ELASTIC PRES-

SURE DRESSINGS AND BY PRESSURE DRESSINGS

IN COMBINATION WITH MULTIPLE INCISION OR RAPID WARMING

These dressings were, in every case, applied after swelling had reached its maximum. They offer the advantage, over closed plaster or plastic dressings, of not requiring immediate application.

Elastic pressure dressings. Elastic pressure dressings, without other treatment, were applied to the feet of rabbits injured by exposure for 3 minutes at $-55^{\circ} \mathrm{C}$., for 2 minutes at $-54^{\circ} \mathrm{C}$., and for 50 minutes at $-15^{\circ} \mathrm{C}$. (Table I). The results should be compared with those obtained in untreated cold injury of similar duration. It is evident that the amount of tissue loss was reduced in most animals. Following 3-minute exposure at $-55^{\circ} \mathrm{C} ., 4$ out of 7 animals lost only the toes. With the 2 less severe degrees of cold injury, parts of the toes were saved in all except 1 animal.
Rapid warming followed by elastic pressure dressings. Rabbits' feet exposed for 3 minutes at $-53^{\circ} \mathrm{C}$. to $-55^{\circ} \mathrm{C}$. or for 60 minutes at $-15^{\circ}$ C. were immediately warmed in water at $+42^{\circ}$ C. for 5 minutes, then permitted to swell for 40 to 180 minutes before application of elastic pressure dressings: In all 8 animals the results were uniformly good (Table I). Following 3-minute exposure at $-55^{\circ} \mathrm{C}$., parts of the toes were saved in 2 animals.

Multiple incision followed by elastic pressure dressings. The method of multiple incision, introduced by Noesske (8), was applied to frostbite by Wittek (9) and Bundschuh (10). Although their results may be questioned on the grounds of inadequate numbers of control cases, the removal of fluid and the establishment of free drainage before application of pressure dressings may seem to be desirable. Seven animals were treated in this manner following 3-minute exposure at $-55^{\circ}$ 
C. (Table I). In the first 6 animals, 3 incisions were made through the skin of the dorsal surface parallel to the long axis of the foot. In the seventh animal similar incisions were made on the toes. In order to encourage free drainage the incisions were packed with a small amount of 5 per cent sulfathiazole cream before application of the pressure dressings. Although the animal in which the toes were incised lost only the toes, the results are not superior to those obtained by means of pressure dressings alone. The added danger of infection probably constitutes sufficient grounds for avoiding this method of treatment in clinical practice.

\section{TREATMENT OF COLD INJURY BY PULSATING EXTERNAL PRESSURE}

Pressure pulses transmitted through tissues from arteries and arterioles have been shown to be one of the important dynamic agencies in the maintenance of lymph flow (11). To the extent that edema following severe injury by cold $(1,2)$ may be responsible for some of the changes leading to gangrene, the acceleration of lymph drainage of edematous areas should be helpful in reversing the processes which lead to the development of gangrene. Even in circumstances where gangrene does not occur, the swelling has been shown to lead to induration and later formation of collagenous scars in the subcutaneous tissues (12). Past experience has shown that most cases of accidental injury by cold, especially in military operations, do not receive treatment until a considerable time after exposure, and edema is then usually well advanced. The literature has been reviewed in the first paper of this series (7).

The experiments below were undertaken to study the effects of external application of pulsating pressure upon the course and ultimate results of severe injury by cold in the feet of rabbits.

\section{Methods}

Fifteen rabbits were used in the study. Thirteen of the animals were subjected to a degree of injury by cold which had been shown to produce extensive gangrene (Table I) ; 3 minutes at $-50^{\circ} \mathrm{C}$. to $-56^{\circ} \mathrm{C}$. The remaining 2 animals received injury to the feet which usually resulted in some gangrene and loss of the toes: 2 minutes at the same temperatures used above.

Treatment was begun at varying times after injury. In all cases swelling was allowed to progress practically to its maximum. The times of application of treatment are indicated in Table IV.

External pulsating pressures were applied to the injured feet by enclosing them in a heavy glass cylinder having an internal diameter of 2 inches. The cylinder was filled with water and connected to the source of pressure with heavy-walled pressure tubing. Various methods were used to maintain a closed system with the foot inside the cylinder. The first method involved the use of a heavy rubber diaphragm, having a hole $2 \mathrm{~cm}$. in diameter in its center. A short cuff of thin-walled latex drain tubing was cemented to the edges of the hole and extended at right angles to the plane of the diaphragm. The hole through the diaphragm and the lumen of the cuff were distended by stretching, and the foot was introduced in such a way that the diaphragm enclosed the leg just above the ankle joint and the cuff extended distally along.the foot. The free margins of the diaphragm were then secured in the manner of a gasket to the end of the glass cylinder and held in place by a ring plate and bolts. Because of some fear that the closure about the rabbit's legs might occlude venous blood flow or lymph drainage, the tight latex rubber cuff was replaced by a looser one extending proximally from the diaphragm: this was secured about the part of the leg proximal to the diaphragm by a collar of sponge rubber. The first 4 animals listed in Table IV were secured in the apparatus for pulsation by the first method of closure described. The next 3 animals were secured by means of the closure with a sponge rubber collar. The remaining 5 animals were given pulsation treatment under conditions which effectively prevented occlusion of blood flow or lymph drainage by the use of a dipped latex bag with a reinforced collar at the open end. The bag was introduced into the glass cylinder and the open end everted over the open end of the cylinder. This formed a closed system having a flexible portion invaginated to receive the foot.

Two types of apparatus were used as sources of pulsating pressure. Apparatus "A" (Table IV) consisted of a perfusion pump, artificial peripheral resistance, and air chamber. Propulsion of fluid by the pump was effected by the compression and forward movement of fluid in a segment of rubber tubing by 4 brass rollers mounted on the periphery of a rotating drum. Mean pressure level was determined by the compression pressure in a standard artificial peripheral resistance of the Starling type. The frequency of pulsations was determined by the rate of rotation of the drum and the size of the pressure pulses by the degree of compression of the rubber tubing by the rollers.

Apparatus "B" consisted of a pump constructed from a 5-ml. syringe mounted on a universal joint. The plunger of the syringe was moved by the arm of a crank driven through reduction gears. An adjustable air chamber constructed from a $50-\mathrm{ml}$. syringe provided for variable damping of the pulse waves. Frequency of pulsations was altered by changing the drive to the reduction gears, and the volume of the pulse was adjusted by manipulation of the stroke of the syringe plunger. 
TABLE IV

Treatment of frostbite by means of pulsating external pressure

\begin{tabular}{c|c|c|c|c|c}
\hline $\begin{array}{c}\text { Animal } \\
\text { no. }\end{array}$ & $\begin{array}{c}\text { Time elapsed } \\
\text { before treat. }\end{array}$ & Pressure & Rate & $\begin{array}{c}\text { Duration of } \\
\text { pulsation }\end{array}$ & Result \\
\cline { 2 - 3 } & hours & mm. $\mathrm{Hg}$ & puls. per min. & hours & \\
\hline
\end{tabular}

Feet exposed at $-50^{\circ} \mathrm{C}$. to $-55^{\circ} \mathrm{C}$. for 3 minutes

\begin{tabular}{|c|c|c|c|c|c|}
\hline $\begin{array}{r}9 \\
11 \\
13 \\
35 \\
54 \\
63 \\
87 \\
103 \\
116 \\
86 \\
106 \\
133 \\
138 *\end{array}$ & $\begin{array}{r}24 \\
3 \\
2 \\
22 \\
3 \\
4 \\
3 \\
2 \\
1.5 \\
1 \\
22 \\
1 \\
2 \\
3.6 \\
24 \\
2\end{array}$ & $\begin{array}{r}+110 /+90 \\
+111 /+91 \\
+90 /+64 \\
+90 /+64 \\
+41 /+34 \\
+42 /+38 \\
+45 /+35 \\
+30 /-10 \\
+50 /+10 \\
+40 /-30 \\
+40 /-30 \\
+69 /+12 \\
+27 /-43 \\
+10 /-10 \\
+10 /-10 \\
+12 /-8\end{array}$ & $\begin{array}{r}208 \\
208 \\
208 \\
208 \\
208 \\
208 \\
208 \\
60 \\
60 \\
60 \\
60 \\
60 \\
60 \\
24 \\
24 \\
24\end{array}$ & $\begin{array}{l}7 \\
3 \\
2.5 \\
8 \\
3 \\
2.5 \\
2.5 \\
3 \\
5.5 \\
5 \\
5 \\
5.5 \\
5.5 \\
3.5 \\
4 \\
5\end{array}$ & $\begin{array}{l}\text { Lost to level of frostbite } \\
\text { Lost to } 1 \mathrm{~cm} \text {. distal to level of frostbite } \\
\text { Lost to level of frostbite } \\
\text { Lost to } 1 / 2 \mathrm{~cm} \text {. distal to level of frostbite } \\
\text { Lost toes } \\
\text { Lost to level of frostbite } \\
\text { Lost to level of frostbite } \\
\text { Lost to level of frostbite } \\
\text { Lost to level of frostbite } \\
\text { Lost to level of frostbite } \\
\text { Lost to } 1 \text { cm. distal to level of frostbite } \\
\text { Lost to level of frostbite } \\
\text { Lost to level of frostbite }\end{array}$ \\
\hline \multicolumn{6}{|c|}{ Feet exposed at $-55^{\circ} \mathrm{C}$. to $-56^{\circ} \mathrm{C}$. for 2 minutes } \\
\hline 133 & $\begin{array}{l}1.5 \\
1.5\end{array}$ & $\begin{array}{l}+20 /-22 \\
+30 /-30\end{array}$ & 24 & $\begin{array}{l}4.5 \\
5\end{array}$ & $\begin{array}{l}\text { Lost to level of frostbite except } 3 \mathrm{~cm} \text {. tongue of tissue } \\
\text { on plantar surface } \\
\text { Lost toes except first phalanx of } 2 \mathrm{nd} \text {. and } 3 \mathrm{rd} \text {. }\end{array}$ \\
\hline
\end{tabular}

* Frostbite followed by rapid thawing in water at $+42^{\circ} \mathrm{C}$. for 5 minutes.

Nos. 9, 11, 13, 35-Apparatus "A," tight cuff of latex drain tubing.

Nos. 54 and 63-Apparatus "A," sponge cuff.

No. 87-Apparatus "B," sponge cuff.

Nos. 103, 116, 86, 106, 133, 119, 138-Apparatus “B," no cuff.

The type of apparatus used for the treatment of the various animals is indicated in Table IV.

\section{Results}

The pertinent data from these experiments are presented in Table IV. The pulsation rates and the magnitudes of the pulse waves in the first 7 animals were selected to reproduce rather closely the pulsations to be expected in the small arteries of the extremities. The frequencies and magnitudes of pulse waves in the last 6 animals were employed to avoid possible interference with blood flow which might have been encountered with the use of higher pressures and also in order to reproduce influences upon lymph flow which resembled those resulting from muscular activity.

None of the feet treated by external pulsating pressure was found to decrease in volume during the period of treatment. In the interval from 15 to 21 hours after the foot was removed from the pressure cylinder, there was usually some addi- tional swelling amounting to 1 to $3 \mathrm{ml}$. The time course of decreasing foot volume was usually a little more rapid than that of the untreated controls, but the difference was neither marked nor uniform.

The final result of the injury did not differ from that in untreated animals. Exposures of 3-minute duration to the freezing mixture at $-50^{\circ} \mathrm{C}$. to $-56^{\circ} \mathrm{C}$. produced gangrene and loss of the foot to within a few millimeters of the line of immersion, and 2-minute exposures to these temperatures was followed by loss of the toes. The time interval between the exposure to cold and the loss of tissue was the same as that in the controls.

\section{STATISTICAL SUMMARY OF RESULTS}

Analysis of the results was carried out by the "exact" method of Fisher (13) for 4-fold tables. The criterion of comparison of control animals with treated animals depended upon the distribution of degrees of tissue loss in the controls. None 
of the control animals fell into class I or II (partial loss of toes or complete loss of toes). Therefore, the treated animals were compared with the controls on the basis of the number of animals in each series which fell into tissue loss classification I and II as distinguished from those falling into classes III to VII. Thus, for purposes of statistical analysis, no result was regarded as favorable unless the loss of tissue was restricted to the toes or parts of toes. Only the data from animals injured by exposure for 3 minutes at $-50^{\circ} \mathrm{C}$. to $-56^{\circ} \mathrm{C}$. were included in the statistical analysis. The values of $\mathrm{P}$ in Table $\mathrm{V}$ indicate for each type

TABLE V

Statistical summary of results ${ }^{4}$

\begin{tabular}{l|c|c}
\hline \hline \multicolumn{1}{c|}{ Treatment } & $\begin{array}{c}\text { Num- } \\
\text { ber of } \\
\text { ani- } \\
\text { mals }\end{array}$ & $P$ \\
\hline Rapid warming and plastic cast & 6 & 0.000020 \\
Rapid warming and pressure dressing & 5 & 0.000038 \\
Plaster cast & 4 & 0.000170 \\
Pressure dressing & 7 & 0.003300 \\
Plastic cast and cooling & 6 & 0.011000 \\
Plastic cast & 9 & 0.032000 \\
Rapid warming, plastic cast, and cooling & 5 & 0.034000 \\
Multiple incision and pressure dressing & 7 & $0.076000^{*}$ \\
Pulsating pressure & 13 & $0.433300^{* *}$ \\
\hline
\end{tabular}

* Difference from controls of doubtful statistical significance.

** Difference from controls not statistically significant.

of treatment the probability of encountering the indicated reduction in tissue loss by chance. The various treatments are arranged in the order of their effectiveness in preventing gangrene. The probability values indicate that significant degrees of benefit were achieved by the use of nondistensible dressings and by pressure dressings, but favorable results were even more frequently encountered when these dressings were combined with other treatments, especially immediate rapid warming.

\section{DISCUSSION}

The methods of treatment of cold injury described in this report have in common the attempt to control fluid loss from the blood stream in the region injured by cold. As measures of prevention, control has been effected through the application of non-distensible dressings before swelling occurred; as aids to the removal of edema fluid,

\footnotetext{
4 See text for basis of comparison and method of computing values for $P$.
}

elastic pressure dressings; the incision of swollen tissues, and the application of external pulsating pressure have been employed. The results show that prevention of swelling or the reduction of it by means of elastic pressure dressings is capable of altering the course of changes in tissues severely injured by cold. In contrast to the complete loss from gangrene of the part subjected to injury when no treatment is used, there is a striking reduction in the extent of gangrene following the application of a non-distensible dressing before swelling has occurred or the use of an elastic pressure dressing after swelling is maximal. In general, the amount of tissue saved by the use of measures designed to control swelling are somewhat smaller than the proportion saved by immediate, rapid warming (12). However, the best results obtained with pressure dressing or with casts are equal to those following rapid warming in terms of amount of tissue saved and much superior to those obtained by rapid warming in terms of functional recovery. Cold-injured tissues which escape gangrene and survive following treatment by immediate, rapid warming are thickened by massive induration in the early healing period and later by dense accumulations of collagenous scar tissue. If the injuries are treated by casts or pressure dressings, alone or in addition to rapid warming, induration and accumulations of scar tissue are insignificant.

The success or failure of treatment of cold injury by the application of casts or pressure dressings depended to an important degree upon the manner of application of the dressing and also upon the nature of the material used for padding. Unequal distribution of pressure, especially over bony prominences, contributed greatly to the development of gangrene. The irregular contours of the rabbits' feet, after removal of the hair by clipping, proved to be extremely difficult to pad evenly. Of the various materials tried as padding (paper wadding, absorbent cotton, gauze, and lamb's wool), the wool was the most satisfactory in both casts and pressure dressings. Both paper and cotton tended to become matted and stiff with absorbed exudate, while the lamb's wool without losing resilience permitted the continued drainage of exudate. The almost invariable loss of the toes following the severest injury (exposure of 3 minutes at $-55^{\circ}$ C.) and the partial loss of 
toes following the less severe degrees of injury may be attributed in part to unsatisfactory application and maintenance of pressure in these parts of the feet. The relationship between the mass and the surface area of the toes tended to facilitate their reaching a lower temperature during exposure, and the larger number of arteriovenous anastomoses contributed to early stasis by diverting blood flow away from the true capillaries (2). The above factors and undoubtedly others, as yet undefined, combine to determine the greater susceptibility of the toes to cold injury.

The results of treatment of cold injury by early mechanical control of the edema, by immediate rapid warming (12), and by the use of heparin as described by Lange and Boyd (14) all confirm the opinion of Bigelow (15) that stasis is not necessarily an irreversible process. The interruption of the transition from temporary arrest of blood flow by stasis to permanent arrest by thrombosis may be accomplished by a variety of means. In spite of the apparently diverse mechanisms of action of these methods of treatment, they have in common the essential feature that all of them must be applied early and continuously over an appreciable time period in order to be effective.

It should be pointed out that the "reversal of stasis," in the literal sense of restoration of blood flow through the identical capillaries once occluded by packed red blood cells, is not a necessary condition determining the survival of tissues severely injured by cold. However it may be accomplished, the necessary condition is the supply of oxygen and nutrients and the removal of metabolites. Resting tissues are maintained under normal conditions with blood flowing through only a very few of the total number of capillaries available, the flux of tissue fluid being adequate for the supply of cells remote from open capillaries (16). If such a flow of fluid can be maintained for a sufficient time in tissues severely injured by cold, new capillary channels may grow to replace those obliterated, initially by stasis and later by thrombosis.

In untreated experimental frostbite, the development of massive edema is accompanied by rising interstitial fluid pressure (17). When the edema reaches its maximum (about 2 hours after the severest forms of injury described in this report) the interstitial fluid pressure is $25 \mathrm{~cm}$. of water.
Not only is the rate of filtration sharply limited by the high counterpressure, but many of the minute vessels become closed, both by the rise of pressure surrounding the vessel above that within the lumen and by kinking as the tissues are distorted by edema. An additional harmful consequence of edema is the increased distance over which diffusion exchanges must be accomplished between remaining capillaries and surviving cells.

It is probably safe to assume that the fluid dynamics are essentially the same inside the nondistensible dressings used for the treatment of frostbite as those described by Glenn, Gilbert, and Drinker (5) when such dressings were used for the treatment of experimental burns. Even though a high rate of fluid loss from capillaries may persist, the rigid dressing enforces a uniform rise of pressure in all parts of the foot enclosed within the cast; spatial distortion is prevented and rapid removal of fluid is effected via the lymphatics as well as by seepage through the interstitial compartment. The mechanism of action of elastic pressure dressings is conceived to be fundamentally similar with the exception that such dressings are applied after swelling and hence have, in the early phases, a dynamic rather than a passive role in removal of fluid.

In untreated experimental frostbite, the skin temperature of injured feet of rabbits declined gradually over a period of about 48 hours until the temperature was approximately that of the environment (1). When skin temperature measurements were made on casted feet by means of thermocouples on the skin and enclosed in the cast, it was found that those parts which survived the injury remained warm while those destined to become gangrenous in spite of the treatment suffered the usual fall in temperature. It therefore seems evident that arrest of the usual process of progressive vascular occlusion is in some way brought about by the cast or pressure dressing. Removal of dressings as early as the third or fourth day after injury resulted in gangrene and loss of the entire injured region. Thus, the interruption of the injury process does not become stabilized until the dressings have been left in place for 5 to 7 days. While the exact nature of the change is not known, the time relations are at least consistent with the following hypothetical course of events: (a) primary stasis of true capillaries following the 
initial injury, (b) persistence of filtration from arteriolar-venular capillaries (16) in amounts sufficient to maintain cells which survive the original injury, (c) the growth of new capillaries in sufficient numbers to provide for fluid removal and maintenance of cells by the time the dressings are removed.

\section{SUMMARY}

Prevention of gangrene following experimental frostbite in the hind feet of rabbits was attempted by mechanical control of edema with casts and pressure dressings. Combinations of rapid warming and subsequent cooling with casts and pressure dressings were also studied.

The injuries were of sufficient severity (immersion in liquid for 3 minutes at $-55^{\circ} \mathrm{C}$.) to produce loss of virtually all of the exposed part of the foot in control animals. In similarly injured animals, treated by the above methods, marked improvement was noted. Gangrene was restricted to the toes or parts of the toes in a highly significant number of cases.

The most favorable results were obtained by the use of rapid warming followed either by casts applied before swelling occurred or by pressure dressings applied after maximum swelling. Casts or pressure dressings alone produced significantly favorable results. The maintenance of low skin temperatures $\left(5^{\circ}\right.$ to $10^{\circ} \mathrm{C}$.) in casted frostbitten feet produced better results than did casts alone, but the difference was slight. Multiple incisions through the skin of the injured regions, followed by the application of pressure dressings, led to survival of more tissue in the frostbitten feet than was observed in the controls; but the low statistical significance of the difference suggests that the procedure is of doubtful value. External application of pulsating pressure was completely ineffective in preventing gangrene.

Various factors influencing the successful use of the treatments have been discussed and a possible mechanism by which control of edema may prevent gangrene was suggested.

The authors extend thanks to Professor F. W. Weymouth for his advice in the preparation of this manuscript and for the statistical treatment of data.

\section{BIBLIOGRAPHY}

1. Fuhrman, F. A., and Crismon, J. M., Studies on gangrene following cold injury: II. General course of events in rabbit feet and ears following untreated cold injury. J. Clin. Invest., 1947, 26, 236.

2. Crismon, J. M., and Fuhrman, F. A., Studies on gangrene folowing cold injury: VI Capillary blood flow after cold injury, the effects of rapid warming and sympathetic block. J. Clin. Invest., 1947, 26, 468.

3. Harkins, H. N., The Treatment of Burns. C. C. Thomas, Springfield, Ill., 1942.

4. Glenn, Wm. W. L., A physiological analysis of the nature and of the treatment of burns. Ann. Surg., 1944, 119, 801.

5. Glenn, Wm. W. L., Gilbert, Helen H., and Drinker, C. K., The treatment of burns by the closed plaster method, with certain physiological considerations implicit in the success of this technique. J. Clin. Invest., 1943, 22, 609.

6. Allen, H. S., and Koch, S. L., The treatment of patients with severe burns. Surg., Gynec. and Obstet., 1942, 74, 914.

7. Fuhrman, F. A.; and Crismon, J. M., Studies on gangrene following cold injury: I. A method for producing gangrene by means of controlled injury by cold. J. Clin. Invest., 1947, 26, 229.

8. Noesske, H., Zur Prophylaxe und Therapie drohender Fingergangrän bei Raynaudsche Krankheit. Münch. med. Wschr., 1909, 56, 2419.

9. Wittek, A., Zur Behandlungen der Erfrierungen. Münch. med. Wschr., 1915, 62, 416.

10. Bundschuh, E., Ueber Behandlungen der Erfrierungen. Münch. med. Wschr., 1915, 62, 416.

11. Gesell, R., The relation of pulsation to filtration. Am. J. Physiol., 1914, 34, 186.

12. Fuhrman, F. A., and Crismon, J. M., Studies on gangrene following cold injury: VII. Treatment of cold injury by means of immediate rapid warming. J. Clin. Invest., 1947, 26, 476.

13. Fisher, R. A., Statistical Methods for Research Workers, par. 21.02. Oliver and Boyd, Edinburgh, 1936.

14. Lange, Kurt, and Boyd, L. J., The functional pathology of frostbite and the prevention of subsequent gangrene. Surg., Gynec. and Obstet., 1945, 80, 346.

15. Bigelow, W. G., Modern conception and treatment of frostbite: survey and discussion of literature. Canad. M. A. J., 1942, 47, 529.

16. Zweifach, B. W., The structural basis of permeability and other functions of blood capillaries. Cold Spring Harbor Symp. Quant. Biol., 1940, 8, 216.

17. Fuhrman, F. A., and Crismon, J. M., Studies on gangrene folowing cold injury: III. Edema following cold injury: its magnitude and the composition and source of edema fluid. J. Clin. Invest., 1947, 26, 245. 